TAPROBANICA, ISSN 1800-427X. April, 2013. Vol. 05, No. 01: 12-18. (C) Taprobanica Private Limited, 146, Kendalanda, Homagama, Sri Lanka. www.taprobanica.org

\title{
GASTROPOD SHELL UTILIZATION PREFERENCES OF HERMIT CRAB Clibanarius zebra (DANA, 1852) (DIOGENIDAE: ANOMURA)
}

\author{
J. N. Trivedi ${ }^{1}$, S. Arya ${ }^{1}$ and K. D. Vachhrajani ${ }^{1,2}$
}

\footnotetext{
${ }^{1}$ Division of Environment and Toxicology, Department of Zoology, Faculty of Science, The M. S. University of Baroda, Vadodara 390002, Gujarat, India; E-mail: kauresh@gmail.com²
}

\begin{abstract}
The aim of the present study was to characterize the patterns of gastropod shell utilization by the hermit crab Clibanarius zebra (Dana, 1852) from four different sites along the Saurashtra coast, Gujarat state, India. A total of 404 individuals of hermit crab were captured (223 males, 147 females and 34 ovigerous females), occupying 22 species of gastropod shells. Maximum species diversity of shells occupied by the crab was observed at Veraval. Amongst all the shell species identified, Cerithium scabridum (36.88 \%) was highly occupied by the crab species followed by Astra stellata (11.39\%), Turbo intercostalis (10.64 \%), Cerithidia cingulata (9.16 \%) and Lunella coronata (7.43 $\%$ ). Males of $C$. zebra utilized a wide range of shell species (21 species), while non ovigerous females (13 species) and ovigerous females $(7$ species) use a specific set of gastropod shell species. The density of live common shell species occupied by C. zebra was also calculated and results revealed that the density of $C$. scabridum was very high in the intertidal zone compared to other gastropods. This indicates that density of shells may influence the utilization of shells by C. Zebra.
\end{abstract}

Key words: Saurashtra coast, gastropod shell density, shell occupancy, India

\section{Introduction}

Benthic fauna show complex patterns in their bioecological relationships and these relationships play important roles in the maintenance of different structural parameters of benthic communities such as density, biomass, species richness and spatiotemporal distribution of species (Tait \& Dipper, 1998, Lawal-Are et al., 2010, Pandya \& Vachhrajani, 2010; Trivedi et al., 2012). Hermit crabs
(Anomura: Diogenidae) normally use gastropod shells as shelter to avoid mechanical damage to the body as their abdomen lacks calcification (Barnes, 2003) and to get proper protection from predators. Hermit crabs obtain empty gastropod shells from the habitat where available (Tricarico \& Gherardi, 2006). Shell species and shell morphology have evident effects on hermit crab's growth rate (Bertness, 
1981), clutch size and fecundity, (Childress, 1972; Turra \& Leite, 2001) and susceptibility to predation (Mima et al., 2003). In general, the survival of a hermit crab population in a particular area is limited by the shell availability (Kellogg, 1976; Floeter et al., 2000) and hermit crabs follow particular patterns of gastropod shell selection, based on adequacy and availability of gastropod shell resources (Reese, 1962; Conover, 1978).

The intertidal area of Saurashtra coast, Gujarat, India is narrow in width and mostly rocky in nature. The upper intertidal zone is composed of sandy shore while the lower intertidal zone is composed of ancient lime stones called milliolite. The marine biodiversity of the area includes 120 species of macrofauna recorded so far (Vaghela, 2010). Two species of hermit crabs (C. nathii and C. zebra) are commonly observed in the intertidal area of Saurashtra coast (Vaghela \& Kundu, 2012). Desai \& Mansuri (1989) have studied the different abiotic and biotic factors, like salinity fluctuation in sea water, desiccation stress, substratum preference, temperature, and $\mathrm{pH}$, that affect density, abundance and spatiotemporal distribution of $C$. zebra and $C$. nathii at various sites on the Saurashtra coast. In the present study we have studied the distribution, density and gastropod shell utilization patterns of the hermit crab Clibanarius zebra.

\section{Materials and Methods}

The present study was carried out at four different sites along the coastal region of Saurashtra, Gujarat, India viz., Veraval (20 54' 37" N, 70 21' 04" E), Sutrapada (20 49' 53" N, 70 29' 17' E) Dhamlej (20 46' 29" N, 70 36' 19" E) and Kodinar (20 45' 29" N, 70 39' 39" E). The intertidal area of all the studied sites shows evident zonation patterns which were identified based on physiographic features and dominant species in the community. The intertidal zone of Veraval is mostly rocky, while the upper intertidal zone is composed of sandy shore. The lower intertidal area grades into a subtidal zone with a steep slope. The exposure of the intertidal zone is not uniform and shows a maximum exposure of 60 to $90 \mathrm{~m}$ at different tidal levels. The rocky intertidal area of Veraval is mostly covered by small tide pools of varied depth, small boulders, and crevices, which provide suitable habitat for gastropods and hermit crab species. The intertidal areas of Sutrapada and Dhamlej are flat and rocky in nature with maximum exposure of 120 to $130 \mathrm{~m}$. The intertidal zone of both the sites is shallow and presents small tide pools with sandy or algae-covered substrata. The intertidal zone at Kodinar is also flat with numerous small tide pools with maximum exposure of $120-130 \mathrm{~m}$. The lower intertidal zone contains large tide pools filled with zoanthids, while the upper intertidal zone is made up of sandy shore. Along the coast, about 1 to $1.5 \mathrm{~km}$ of the shore line at all the study sites was explored.

To study the gastropod species utilization by hermit crabs, systematic sampling was done between March 2012 and August 2012. For the collection of crabs, each of the study sites was marked with 10 line transects perpendicular to the coast line and at least $100 \mathrm{~m}$ apart where the length of transects varied with the extent of exposure during low tide. On each transect four quadrates of $0.25 \mathrm{~m}^{2}$ were laid randomly. The C. zebra individuals present in the quadrate area were collected and brought to the lab. To calculate the density of the gastropod shells in the study area, 40 quadrates were laid as described above. All the gastropod shells available in the quadrate area were counted and identified to the species level using identification key (Apte, 1998). In the laboratory, the crabs were classified into three categories on the basis of gender and reproductive status viz male, non ovigerous female and ovigerous female. The gastropod shells occupied by $C$. zebra were also identified to the species level.

A Pearson's $\chi^{2}$ test was used to compare the shell occupation frequencies by hermit crab while one way ANOVA was used to compare the mean density of gastropod shells.

\section{Results \\ During the study period a total of 404 hermit crabs were collected; amongst them 223 (55\%) individuals were male, 147 were female $(36 \%)$ and $34(8 \%)$ were ovigerous females (Table I). The hermit crabs were found occupying 22 species of gastropods shells in different percentages, (Table 1) of which six species of gastropod shells were most commonly utilized by the hermit crabs. Cerithium scabridum was observed to be the most frequently occupied gastropod shell species $\left(37 \%, \chi^{2}=6.38, \mathrm{P}<\right.$}


0.05 ) by the $C$. zebra population followed by Astrea stellata $(11 \%, \chi 2=58.1, \mathrm{P}<0.05)$, Turbo intercostalis $(11 \%, \chi 2=60.40, \mathrm{P}<$ $0.05)$, Cerithidia cingulata $\left(9 \%, \chi^{2}=65.10, \mathrm{P}\right.$ $<0.05)$, Lunella coronata $(7 \%, \chi 2=70.80, \mathrm{P}<$ $0.05)$ and Chicoreus brunneus (5 \%, $\chi^{2}=$ $60.40, \mathrm{P}<0.05$ ), which were also significantly occupied by the hermit crab species (Fig. 1). The remaining species of gastropod shells showed variation in percentage of occupation $(0.25 \%$ to $3.47 \%)$ and represented $19.05 \%$ of the total utilization of occupied shell species. They were assembled in one group and named as "others".

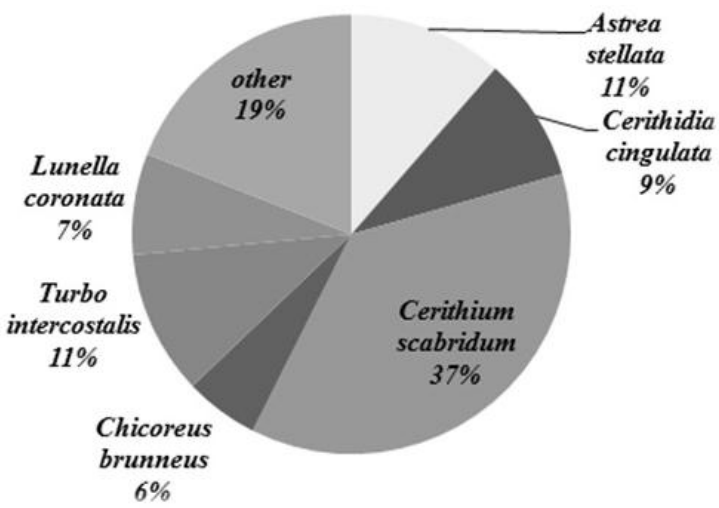

Figure 1: Percentage utilization of gastropod shells by $C$. zebra

The species diversity of gastropod shells occupied by hermit crabs was analysed and revealed that from the total of 22 species of gastropod shells used by $C$. zebra, the maximum species diversity was recorded at Veraval (20 species) followed by Kodinar (17 species), Sutrapada (13 species), and Dhamlej (10 species) (Table 2). A difference in the gastropod species utilization by different sexes of $C$. zebra was observed. Males utilized 21 species of gastropod shells while non ovigerous females utilized 19 species and ovigerous females utilized 7 species (Table 2). Six species of gastropod shells; Cerithium scabridum, Astrea stellata, Lunella coronata, Cerithidia cingulata, Chicoreus brunneus, and Turbo intercostalis were commonly utilized by all the categories where the percentage utilization of these shells varied considerably. In the case of ovigerous females, utilization of Lunella coronata and Chicoreus brunneus was not observed indicating species preference/ avoidance. Ovigerous females showed greater usage of Purpura panama and Thais lacera than males and all females.
Amongst the six species of gastropod shells utilized by the hermit crab species, Cerithium scabridum was significantly occupied by males $\left(24 \%, \chi^{2}=26.96, \mathrm{P}<0.05\right)$ but in the case of non ovigerous females $(50 \%)$ and ovigerous females $(53 \%)$ significance in occupation was not observed. The other five species of gastropod shells significantly occupied by males were Astrea stellata $\left(13 \%, \chi^{2}=52.60, \mathrm{P}\right.$ $<0.05)$, Lunella coronata $(12 \%, \chi 2=56.64, \mathrm{P}$ $<0.05)$, Cerithidia cingulata $(5 \%, \chi 2=79.14$, $\mathrm{P}<0.05)$, Chicoreus brunneus $(9 \%, \chi 2=$ $77.62, \mathrm{P}<0.05)$, and Turbo intercostalis (15\%, $\left.\chi^{2}=47.08, \mathrm{P}<0.05\right)$ and by non ovigerous females were Astrea stellata $(10 \%, \chi 2=63.72$, $\mathrm{P}<0.05)$, Lunella coronata $(3 \%, \chi 2=87.40, \mathrm{P}$ $<0.05)$, Cerithidia cingulata $\left(15 \%, \chi^{2}=47.44\right.$, $\mathrm{P}<0.05)$, Chicoreus brunneus $(1 \%, \chi 2=$ $65.18, \mathrm{P}<0.05)$, and Turbo intercostalis (4\%, $\left.\chi^{2}=82.12, \mathrm{P}<0.05\right)$. For ovigerous females, Astrea stellata $(8 \%, \chi 2=62.20, \mathrm{P}<0.05)$, Cerithidia cingulata $\left(11 \%, \chi^{2}=65.18, \mathrm{P}<\right.$ $0.05)$, and Turbo intercostalis $(5 \%, \chi 2=76.10$, $\mathrm{P}<0.05)$ were significantly occupied while utilization of Lunella coronata and Chicoreus brunneus was not observed. Ovigerous females showed significantly greater usage of Purpura panama $\left(5 \%, \chi^{2}=76.10, \mathrm{P}<0.05\right)$ and Thais lacera $\left(5 \%, \chi^{2}=76.10, \mathrm{P}<0.05\right)$, which were not commonly utilized by males or non ovigerous females (Fig.2-3).

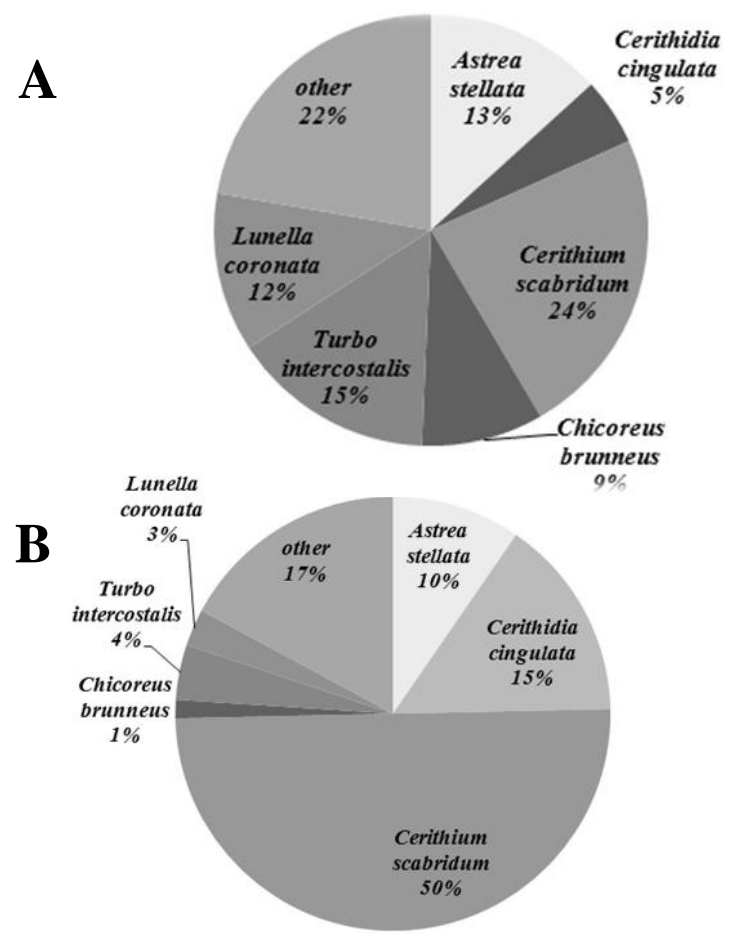

Figure 2: Percentage utilization of gastropod shells by (A) male (B) female $C$. zebra 


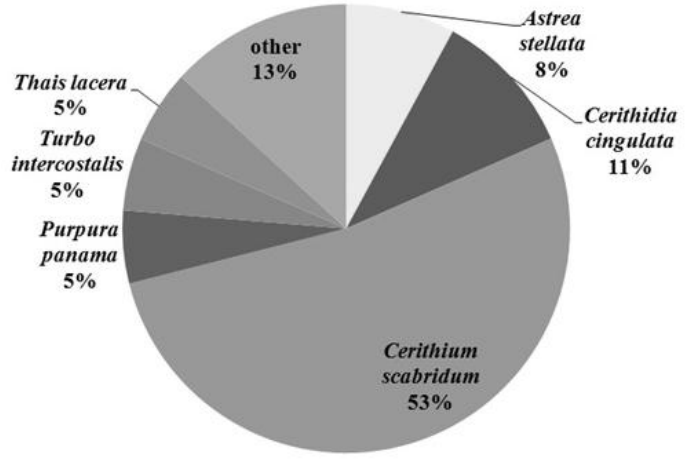

Figure 3: Percentage utilization of gastropod shells by ovigerous female $C$. zebra

Shell availability in the habitat is the main factor affecting the shell utilization and survival of the hermit crab population in a particular area (Kellogg, 1976; Floeter et al., 2000). During the study we collected data on the density of gastropod species which are commonly utilized by the hermit crab to determine the shell resources available in the habitat for hermit crab utilization. The results revealed that significant variation is observed for the mean density values of each shell species (ANOVA: $\mathrm{df}=71, \mathrm{~F}=17.58, \mathrm{p}<$ 0.05). Cerithium scabridum exhibited maximum density followed by Lunella coronata, Turbo intercostalis, Cerithidia cingulata, Astrea stellata, and Chicoreus brunneus (Fig. 4).

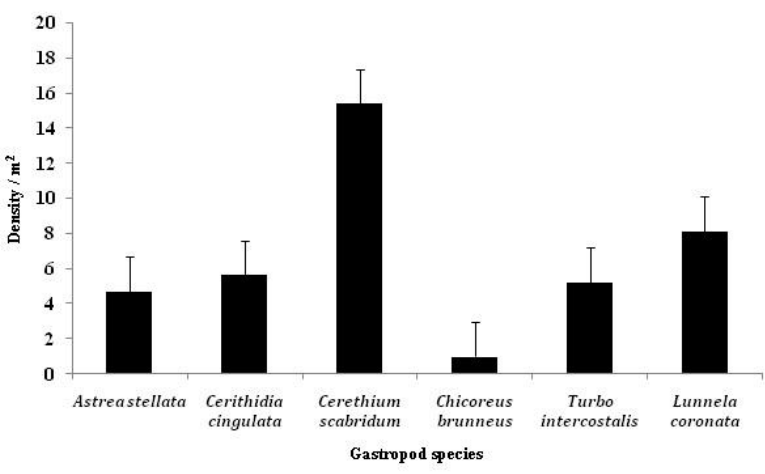

Figure 4: Density of gastropod species

\section{Discussion}

The population distribution of hermit crabs has an adequate relationship with the gastropod species available in the habitat (Mantellato \& Garcia, 2000). The survival of hermit crabs in a particular area and their gastropod shell utilization patterns depend on different factors such as special architecture of the shell resource, density of shells, and inter- and intraspecific competition between different crab species (Reese, 1962, 1969). In the present study, Clibanarius zebra was found to utilize 22 species of gastropod shells and similar results were obtained for other species of the same genera. For example, Clibanarius erythropus utilizes 19 species of gastropod shells (Botelho \& Costa, 2000), while Clibanerius virescens was observed to utilize 23 species of gastropod shells (Reddy \& Biseswar, 1993). Fatima (2007) has studied the gastropod species utilization by hermit crab species Diogenes planimanus at Karanchi coast of Pakistan and recorded utilization of 32 gastropod species which is quite higher than the utilization pattern of gastropod shell by $C$. zebra.

In the present study, male and non ovigerous female crabs utilized 21 and 19 species of gastropod shells respectively but lower diversity of gastropod shell utilization was observed in ovigerous females. A total of 7 species of gastropod shells were occupied by ovigerous females out of 22 species recorded from the habitat. Similar results have been recorded in ovigerous female gastropod shell occupation for two different species, Calcinus tibicen (Mantelatto \& Garcia, 2000) and Pagarus exilis (Terossi et al., 2006). Present findings suggest that a specific pattern of shell selection is observed in case of ovigerous females. Further, differences have been observed for the occupation of common gastropod species by different sexes of the crab species. Shells of $C$. scabridum, A. stellta, $C$. cingulata, and $T$. intercostalis were most occupied by male, non ovigerous female and ovigerous females while other species, namely $L$. coronata and $C$. brunneus, were occupied only by males and non ovigerous females but not utilized by ovigerous females.

C. Zebra utilizes a wide range of gastropod shells, and this particular pattern suggests that the occupation of shells is highly influenced by shell availability in the area. It was also observed that in the local population of $C$. $z e b r a$, specific preference was observed for Cerithium scabridum which suggests that there may be a pattern of preference and adaptation by $C$. Zebra for this gastropod species. A similar pattern has been observed for Isocheles sawayai, which uses the shells of Stramonita haemastoma (Galindo et al., 2008). In the present study, C. zebra utilized Cerithium scabridum maximally (37\%), however, it was 
quite lower than the shell utilization pattern exhibited by hermit crabs C. vittatus $(64.7 \%)$ and Isocheles sawayai which utilized the gastropod Stramonita namastomai shell to the extent of $64.7 \%$ and $49.87 \%$, respectively (Fantucci et al., 2008; Sampaio \&Masunari, 2010). A high density of Cerithium scabridum was recorded (15 animals $\left./ \mathrm{m}^{2}\right)$ as compared to other shells, which makes it the dominant gastropod species of the habitat and thus represents an adequate shell resource for occupation by hermit crab species. The distribution of Cerithium scabridum and $C$. $z e b r a$ is observed on the entire Saurashtra coast indicating overlapping of geographical distribution (Apte, 1998, Vaghela \& Kundu, 2012). On the basis of this particular phenomena and shell utilization it is thought that the shell availability in the habitat is the main reason for the utilization of Cerithium scabridum by the hermit crab C. zebra. The specific selection of gastropod shell species by the ovigerous females needs further study.

Table 1: Percentage of gastropod species utilized by Clibanarius zebra

\begin{tabular}{|c|c|c|c|c|c|c|c|c|}
\hline \multirow[t]{2}{*}{ Gastropod species } & \multicolumn{2}{|c|}{ Total } & \multicolumn{2}{|c|}{ Male } & \multicolumn{2}{|c|}{ Female } & \multicolumn{2}{|c|}{$\begin{array}{c}\text { Ovigerous } \\
\text { female }\end{array}$} \\
\hline & $\mathbf{n}$ & $\%$ & $\mathbf{n}$ & $\%$ & $\mathbf{n}$ & $\%$ & $\mathbf{n}$ & $\%$ \\
\hline Astrea semicostata & 7 & 1.73 & 6 & 2.69 & 1 & 0.68 & 0 & 0 \\
\hline Astrea stellata & 46 & 11.39 & 29 & 13.00 & 14 & 9.52 & 3 & 8.82 \\
\hline Bursa granularis & 6 & 1.49 & 3 & 1.35 & 3 & 2.04 & 0 & 0 \\
\hline Cantharus spiralis & 2 & 0.50 & 1 & 0.45 & 1 & 0.68 & 0 & 0 \\
\hline Cantharus undosus & 12 & 2.97 & 10 & 4.48 & 2 & 1.36 & 0 & 0 \\
\hline Cerithidia cingulata & 37 & 9.16 & 11 & 4.93 & 22 & 14.97 & 4 & 11.76 \\
\hline Cerithium rubes & 12 & 2.97 & 4 & 1.79 & 7 & 4.76 & 1 & 2.94 \\
\hline Cerithium scabridum & 149 & 36.88 & 55 & 24.66 & 74 & 50.34 & 20 & 58.82 \\
\hline Chicoreus brunneus & 22 & 5.45 & 20 & 8.97 & 2 & 1.36 & 0 & 0 \\
\hline Engina zea & 4 & 0.99 & 1 & 0.45 & 3 & 2.04 & 0 & 0 \\
\hline Lunella coronata & 30 & 7.43 & 26 & 11.66 & 4 & 2.72 & 0 & 0 \\
\hline Mitra guttata & 1 & 0.25 & 0 & 0.00 & 1 & 0.68 & 0 & 0 \\
\hline Mitra scutulata & 3 & 0.74 & 2 & 0.90 & 1 & 0.68 & 0 & 0 \\
\hline Nassarius lentigenosus & 1 & 0.25 & 0 & 0.00 & 1 & 0.68 & 0 & 0 \\
\hline Nassarius reeveanus & 1 & 0.25 & 1 & 0.45 & 0 & 0.00 & 0 & 0 \\
\hline Nassarius sufflatus & 1 & 0.25 & 1 & 0.45 & 0 & 0.00 & 0 & 0 \\
\hline Polia rubigenosa & 2 & 0.50 & 2 & 0.90 & 0 & 0.00 & 0 & 0 \\
\hline Purpura panama & 14 & 3.47 & 9 & 4.04 & 3 & 2.04 & 2 & 5.88 \\
\hline Thais lacera & 8 & 1.98 & 5 & 2.24 & 1 & 0.68 & 2 & 5.88 \\
\hline Tibia curta & 1 & 0.25 & 1 & 0.45 & 0 & 0.00 & 0 & 0 \\
\hline Turbo brunneus & 2 & 0.50 & 1 & 0.45 & 1 & 0.68 & 0 & 0 \\
\hline Turbo intercostalis & 43 & 10.64 & 35 & 15.70 & 6 & 4.08 & 2 & 5.88 \\
\hline Total & 404 & 100 & 223 & 100 & 147 & 100 & 34 & 100 \\
\hline
\end{tabular}

Table 2: Gastropod shell diversity at different study sites; V, Veraval; S, Sutrapada; D, Dhamlej; K, Kodinar

\begin{tabular}{l|c|c|c|ccc|c|c|c|c}
\hline \multicolumn{1}{c|}{ Mollusc species } & V & S & D & K & & Mollusc species & V & S & D & K \\
\hline Astrea semicostata & & $\sqrt{ }$ & & $\sqrt{ }$ & Mitra guttata & $\sqrt{ }$ & & \\
Astrea stellata & $\sqrt{ }$ & $\sqrt{ }$ & $\sqrt{ }$ & $\sqrt{ }$ & Mitra scutulata & $\sqrt{ }$ & & \\
Bursa granularis & $\sqrt{ }$ & $\sqrt{ }$ & $\sqrt{ }$ & $\sqrt{ }$ & Nassarius lentigenosus & $\sqrt{ }$ & & \\
Cantharus spiralis & $\sqrt{ }$ & & & $\sqrt{ }$ & Nassarius reeveanus & $\sqrt{ }$ & & \\
Cantharus undosus & & & $\sqrt{ }$ & $\sqrt{ }$ & Nassarius sufflatus & $\sqrt{ }$ & & \\
Cerithidia cingulata & $\sqrt{ }$ & $\sqrt{ }$ & $\sqrt{ }$ & $\sqrt{ }$ & Polia rubigenosa & $\sqrt{ }$ & $\sqrt{ }$ & \\
Cerithium rubes & $\sqrt{ }$ & & & $\sqrt{ }$ & Purpura panama & $\sqrt{ }$ & $\sqrt{ }$ & $\sqrt{ }$ & $\sqrt{ }$ \\
Cerithium scabridum & $\sqrt{ }$ & $\sqrt{ }$ & $\sqrt{ }$ & $\sqrt{ }$ & Thais lacera & $\sqrt{ }$ & $\sqrt{ }$ & $\sqrt{ }$ \\
Chicoreus brunneus & $\sqrt{ }$ & $\sqrt{ }$ & & $\sqrt{ }$ & Tibia curta & $\sqrt{ }$ & $\sqrt{ }$ & $\sqrt{ }$ & $\sqrt{ }$ \\
Engina zea & $\sqrt{ }$ & & & & & Turbo brunneus & $\sqrt{ }$ & $\sqrt{ }$ & $\sqrt{ }$ & $\sqrt{ }$ \\
Lunella coronata & $\sqrt{ }$ & $\sqrt{ }$ & $\sqrt{ }$ & $\sqrt{ }$ & Turbo intercostalis & $\sqrt{ }$ & $\sqrt{ }$ & $\sqrt{ }$ & $\sqrt{ }$ \\
\hline
\end{tabular}


Table 3: Gastropod shell preferences by different categories of Clibanarius zebra

\begin{tabular}{|c|c|c|c|}
\hline Mollusc species & Male & Non ovigerous Female & Ovigerous \\
\hline Astrea semicostata & $\sqrt{ }$ & $\sqrt{ }$ & \\
\hline Astrea stellata & $\sqrt{ }$ & $\sqrt{ }$ & $\sqrt{ }$ \\
\hline Bursa granularis & $\sqrt{ }$ & $\sqrt{ }$ & \\
\hline Cantharus spiralis & $\sqrt{ }$ & $\sqrt{ }$ & \\
\hline Cantharus undosus & $\sqrt{ }$ & $\sqrt{ }$ & \\
\hline Cerithidia cingulata & $\sqrt{ }$ & $\sqrt{ }$ & $\sqrt{ }$ \\
\hline Cerithium rubes & $\sqrt{ }$ & $\sqrt{ }$ & $\sqrt{ }$ \\
\hline Cerithium scabridum & $\sqrt{ }$ & $\sqrt{ }$ & $\sqrt{ }$ \\
\hline Chicoreus brunneus & $\sqrt{ }$ & $\sqrt{ }$ & \\
\hline Engina zea & $\sqrt{ }$ & $\sqrt{ }$ & \\
\hline Lunella coronata & $\sqrt{ }$ & $\sqrt{ }$ & \\
\hline Mitra guttata & & $\sqrt{ }$ & \\
\hline Mitra scutulata & $\sqrt{ }$ & $\sqrt{ }$ & \\
\hline Nassarius lentigenosus & $\sqrt{ }$ & $\sqrt{ }$ & \\
\hline Nassarius reeveanus & $\sqrt{ }$ & & \\
\hline Nassarius sufflatus & $\sqrt{ }$ & & \\
\hline Polia rubigenosa & $\sqrt{ }$ & & \\
\hline Purpura panama & $\sqrt{ }$ & $\sqrt{ }$ & $\sqrt{ }$ \\
\hline Thais lacera & $\sqrt{ }$ & $\sqrt{ }$ & $\sqrt{ }$ \\
\hline Tibia curta & $\sqrt{ }$ & $\sqrt{ }$ & \\
\hline Turbo brunneus & $\sqrt{ }$ & $\sqrt{ }$ & \\
\hline \multirow[t]{2}{*}{ Turbo intercostalis } & $\sqrt{ }$ & $\sqrt{ }$ & $\sqrt{ }$ \\
\hline & 21 & 19 & 7 \\
\hline
\end{tabular}

\section{Acknowledgements}

We are thankful to P. C. Mankodi for his help in identification of gastropod shell species. We also thank Trinayan Borgohin, Umang Trivedi, Vishal Pankhania and Kalpesh Gohel for support during the field studies. Finally we would like to Thank Michelle Wait (Nelson Mandela Metropolitan University - South Africa) and Johanna Bleecker (McGill University - Canada) for editing and reviewing the manuscript.

\section{Literature cited}

Apte, D., 1998. Book of Indian Shells. Bombay Natural History Society, Mumbai, India: 115

Barnes, D. K. A., 2003. Ecology of subtropical hermit crabs in SW Madagascar: short-range migrations. Marine Biology, 142: 549-557.

Bertness, M. D., 1981. The influence of shelltype on hermit crab growth rate and clutch size (Decapoda, Anomura). Crustaceana, 40: 197205.

Bothelho, A. Z. and A. C. Costa, 2000. Shell occupancy of the intertidal hermit crab Clibanarius erythropus (Decapoda, Diogenidae) on S. O Miguel (Azores). Hydrobiologia, 440: 111-117.
Childress, J. R., 1972. Behavioral ecology and fitness theory in a tropical hermit crab. Ecology, 53: 960-964.

Conover, M., 1978. The importance of various shell characteristics to the shell-selection behavior of the hermit crabs. Journal of Experimental Marine Biology \& Ecology, 32: 131-142.

Desai, A. Y. and A. P. Mansuri, 1989. Salinity and desiccation tolerance of hermit crab of Veraval, West coast of India. Indian Journal of Current Biosciences, 8: 129-132.

Fantucci, M. Z., R. Biagi and F. L. M. Mantelatto, 2008. Shell occupation by the endemic western Atlantic hermit crab Isocheles sawayai (Diogenidae) from Caraguatatuba, Brazil. Brazilian Journal of Biology, 68 (4): 859-867.

Fatima, M., 2007. Shell utilization by the hermit crab, Diogenes planimanus (Anomura: Diogenidae) from Karachi coast, Pakistan. Pakistan Journal of Zoology, 39 (4): 233-238.

Floeter, S. R., R. C. Nalesso, M. M. P. Rodrigues and A. Turaa, 2000. Patterns of shell utilization and selection in two sympatric hermit crabs (Anomura, Diogenidae) in south-eastern Brazil. Journal of Marine Biological Association of United Kingdom, 80: 1053-1059. 
Galindo, L. A., J. A. Bolanos and F. L. M, Mantelatto, 2008. Shell utilization pattern by the hermit crab Isocheles sawayai Forest and Saint Laurent, 1968 (Anomura, Diogenidae) from Margarita Island, Caribbean Sea, Venezuela. Caribbean Journal of Science, 20: 49-57.

Kellogg, C. W., 1976. Gastropod shells: a potentially limiting resource for hermit crabs. Journal of Experimental Marine Biology \& Ecology, 22: 101-111.

Lawal-Are, A., R. E. Uwadiae and O. R. Owolabi, 2010. Shell selection of the hermit crab Clibanarius africanus (Aurivillus, 1898) (Decapoda: Diogenidae) in the Lagos lagoon: Aspects of behavioural and bio-ecology of benthos. World Rural Observations, 2 (4): 70-78.

Mantelatto, F. L. M. and R. B. Garcia, 2000. Shell utilization pattern of the hermit crab Calcinus tibicen (Anomura) (Diogenidae) from Southern Brazil. Journal of Crustacean Biology, 20: 460467.

Mima, A., S. Wada and S. Goshima, 2003. Antipredator defense of the hermit crab Pagurus filholi induced by predatory crabs. Oikos, 102: 104-110.

Pandya, P. J. and K. D. Vachharajani, 2010. Spatial distribution and substratum preference of brachyuran crab Macrophthalmus depressus (Decapoda: Ocypodidae) along the lower estuarine mudflats of Mahi River, Gujarat, India. Crustaceana, 83: 1055-1067.

Reddy, T. and R. Biseswar, 1993. Patterns of shell utilization in two sympatric species of hermit crabs from the Natal coast (Decapoda, Anomura, Diogenidae). Crustaceana, 65: 13-24.

Reese, E. S., 1962. Shell selection behaviour of hermit crabs. Animal Behaviour, 10: 347-360.

Reese, E. S., 1969. Behavioral adaptations of intertidal hermit crabs. American Zoology, 9: 343-355.

Sampaio, S. R. and S. Masunari, 2010. Characterization of the occupied shells by the hermit crab Clibanarius vittatus (Decapoda, Diogenidae) at Baixio Mirim tideflat, Guaratuba Bay, southern Brazil. Anais da Academia Brasileira de Ciências, 82: 833-842.
Tait, R. V. and F. A. Dipper, 1998. Elements of Marine Ecology. Butterworth-Heinemann, Oxford: 459.

Terossi, M., D. L. A. Espósito, A. L. Meireles, R. Biagi and F. L. M. Mantelatto, 2006. Pattern of shell occupation by the hermit crab Pagurus exilis (Anomura, Paguridae) on the northern coast of São Paulo State. Brazilian Journal of Natural History, 40: 77-87.

Tricarico, E. and F. Gherardi, 2006. Shell acquisition by hermit crabs: which tactic is more efficient? Behavioral Ecology and Sociobiology, 60: 492-500.

Trivedi, J. N., M. K. Gadhavi and K. D. Vachhrajani, 2012. Diversity and habitat preference of brachyuran crabs in Gulf of Kutch, Gujarat, India. Arthropods, 1 (1): 13-23.

Turra, A. and F. P. P. Leite, 2001. Shell utilization patterns of a tropical rocky intertidal hermit crab assemblage: I. The case of Grande Beach. Journal of Crustacean Biology, 21: 393406.

Vaghela, A., 2010. Spatial and temporal variations in population dynamics of few key rocky intertidal macrofauna at anthropogenically influenced intertidal shoreline. PhD. Thesis, Saurashtra University, Gujarat, India: 215.

Vaghela, A. and R. Kundu, 2012. Spatiotemporal variation of hermit crab (Crustacea: Decapoda) inhabiting rocky shore along Saurashtra coast, Western coast of India. Indian Journal of Geo-Marine Sciences, 41: 146-151. 